\title{
Consumption patterns of rural household in Nanded district
}

N.R. BONKALWAR, D.J. SANAP AND A.P. BABAR

Received : 16.05.2014; Revised : 05.08.2014; Accepted : 18.08.2014

\begin{abstract}
Consumption pattern of rural household in Nanded district was conducted in five villages of Biloli Tahsil in Nanded district. Samples of 200 consisting 50 each landless labours, small, medium and large farmers were selected randomly from selected villages. Data were pertaining to year 2010-11. The lorenze curve for the households was observed to be curved shifted more towards the line of equality in landless labour, small farmer, medium farmer and large farmer in rural household. Gini ratio indicated that the equal distribution income and expenditure of landless labour, small farmer, medium farmer and large farmer of rural household.
\end{abstract}

KEY WORDS : Consumption pattern, Rural household, Income and expenditure

How to cite this paper : Bonkalwar, N.R., Sanap, D.J. and Babar, A.P. (2014). Consumption patterns of rural household in Nanded district. Internat. J. Com. \& Bus. Manage, 7(2) : 269-276.

\section{MEMBERS OF THE RESEARCH FORUM}

Correspondence to:

N.R. BONKALWAR, Vasantrao Naik Marathwada Krishi Vidyapeeth, PARBHANI (M.S.) INDIA

Authors' affiliations:

D.J. SANAP AND A.P. BABAR, Vasantrao Naik Marathwada Krishi

Vidyapeeth, PARBHANI (M.S.) INDIA 